\title{
Foreign direct investment and poverty reduction in sub-Saharan Africa: does environmental degradation matter?
}

\author{
James Temitope Dada ${ }^{1}$ and Taiwo Akinlo ${ }^{2^{*}}$ (i)
}

\begin{abstract}
This paper investigates the threshold effect of environmental degradation on the FDI-poverty nexus in sub-Saharan Africa for the period 1986-2018. The study used panel threshold regression for the empirical analysis. The evidence from threshold regression using different measures of poverty and environmental degradation shows that the poverty reduction effect of FDI is not eroded by environmental degradation. The study found overwhelming evidence that at the higher level of environmental degradation, FDI contributes significantly to poverty reduction except when Household final consumption is used to proxy poverty and FDI produces an insignificant effect on poverty reduction at the higher level of methane emissions and nitrous oxide emission. Based on this finding, any attempts to reduce environmental degradation by reducing the inflow of FDI will worsen poverty rates in the region.
\end{abstract}

Keywords: FDI, Poverty, Threshold regression, Environmental degradation, Sub-Saharan Africa

JEL Classification: F21, F23, O55, Q53, Q56

\section{Introduction}

In the theoretical literature, foreign direct investment (FDI) is expected to reduce poverty through an increase in economic growth. FDI complements domestic investment by providing much-needed financial capital, transfer of valuable technology and know-how through its externalities. However, despite the positive effect of FDI on poverty reduction through economic growth in theoretical studies, previous empirical studies have produced ambiguous results as some studies found a positive relationship (e.g., [3, 10, 21, 29, 42, 53, 62, 67, 69]), while some studies (e.g., $[2,28,43,63]$ found an inverse relationship and Ogunniyi and Igberi [46] found no beneficial effect of foreign direct investment in reducing poverty especially in developing countries which has continually record increase in poverty level despite the massive

\footnotetext{
*Correspondence: taiwoakinlo@yahoo.com

${ }^{2}$ Department of Economics, Adeyemi College of Education, Ondo, Nigeria

Full list of author information is available at the end of the article
}

inflow of foreign direct investment. As noted by Dhrifi et al. [18], most studies that examined the nexus between FDI and poverty reduction focused on the growth channel which could be responsible for the mixed result in the literature. The foreign direct investment comes with some negative externalities, of which one of them is environmental pollution [60,74]. For instance, the negative externalities in terms of production and consumption pollution could worsen environmental quality, economic growth and increase poverty level [18]. This argument suggests that there is a need to consider the role of environmental quality in the FDI-poverty nexus in sub-Saharan Africa as the interdependence between the variables has not received much attention either from academia or policymakers.

The impact of FDI on poverty reduction might significantly be influenced by environmental degradation. That is, FDI can reduce or increase poverty depending on the level of environmental quality. A strong environmental regulation that guarantees sound environmental quality will ensure that the multinational corporations in the 
host country adopt environmentally friendly technologies, clean energy and adopt best international practices which will protect the environment from degradation and hence reduce poverty. This implies that the poverty reduction effect of FDI can be eroded by the decrease in environmental quality in the long run. Likewise, a weak environmental quality will worsen environmental pollution and thereby increase the poverty rates if the attention is focused only on the inflow of FDI without any policies that can protect the environment and the people from unhealthy activities of the multinational corporation.

Based on these premises, there could exist a threshold level of environmental quality where below the threshold level, FDI will significantly worsen the poverty reduction drive of developing countries and above it, FDI will significantly enhance poverty reduction. In addition, empirical evidence from Wang and Liu [71] revealed that there are double threshold levels of environmental regulation and when environmental regulation is between the two thresholds, foreign direct investment reduces poverty in two out of three Chinese regions.

Evidence from the literature shows that many studies (e.g., $[4,19,20,23,33])$ have examined the FDI-poverty reduction nexus in sub-Saharan Africa, but no study has examined the threshold effect of environmental quality on the relationship between FDI and poverty reduction. Thus, this study intends to contribute to the existing studies by investigating the threshold effect of environmental degradation on the relationship between FDI and poverty reduction. This study is very important particularly in sub-Saharan Africa as knowing the threshold point where above and below FDI reduces or increases poverty, respectively, will help researchers, governments and policymakers to formulate policies that will attract FDI, protect the environment and as well reducing the level of poverty.

The contributions of this paper are in fourfold. First, rather than focusing on the relationship between FDI and poverty reduction, the study seeks to investigate the threshold effect of environmental degradation on the relationship between FDI and poverty reduction. Second, aside from estimating the threshold values, we employ the threshold regression that permits the classification of our observations relative to whether or not they exceed the threshold values so that the exact effect of FDI on poverty reduction can easily be obtained for both when the region is below and above the threshold. Third, we use diverse robust variables to measure environmental degradation and poverty reduction for sensitivity analysis and to provide robust findings that will inform adequate policies. For instance, environmental degradation is measured by carbon dioxide emissions per capita, methane emission and nitrous oxide emission while for poverty, household final consumption expenditure, life expectancy and human development index are used as measures. Lastly, the study focuses on a region (sub-Saharan Africa) that has witnessed a massive inflow of foreign direct investment in the past decades and also, increase in her poverty rate. As noted by World Data Lab's Global Poverty Ranking [73], the number of extreme poor rose from 279 million in 1990 to over 400 million and 600 million in 2015 and 2019, respectively, signifying over $70 \%$ of the people living in sub-Saharan African countries lives in extreme poverty. Contrarily, the region witnessed an increase in the inflow of foreign direct investment to the tune of $\$ 42$ billion and $\$ 46$ billion in the year 2017 and 2018, respectively [68]. The rest of the paper is structured as follows: "Literature review" section consists of the methodology and data. "Methods" sections deals with empirical analysis. "Results" section presents the discussion of findings. "Discussion" section outlines the conclusion and policy recommendations.

\section{Literature review}

Empirical studies on the threshold effect of environmental degradation in the nexus between foreign direct investment and poverty are still scare; however, there are studies that examine the relationship among foreign direct investment, poverty and environmental degradation. In this regard, Wang and Huifang [70] applies provincial panel data from 2000 to 2014 to investigate the impact of foreign direct investment and environmental regulation on environmental pollution in China. Applying panel corrected standard error as the estimating technique, the result reveals that stricter environmental regulation abates environmental pollution in all the regions. Furthermore, foreign direct investment reduces environmental pollution in eastern and central regions, but it spurs pollution in the western region. The authors therefore conclude that there is evidence of doublethreshold effects of environmental regulation on the effects of FDI on environmental pollution in each province considered.

In a more recent study, Dhrifi et al. [18], in a panel of 98 developing countries, examine the interrelationship among FDI, carbon dioxide $\left(\mathrm{CO}_{2}\right.$ emission and poverty, using simultaneous equation models between 1995 and 2017. Dividing the sample into sub-sample of Asia, Africa and Latin America, the authors found a two-way causality between foreign direct investment and poverty; and $\mathrm{CO}_{2}$ emission and poverty. Further, the authors conclude that FDI and poverty are negatively correlated for all the regions apart from the African region. Meanwhile, study by Rizk and Slimane [55] examines the relationship between poverty and carbon dioxide $\left(\mathrm{CO}_{2}\right)$ emission in 
146 nations over the period 1996 and 2014 using institutions as the moderating variable. Applying three-stage least squares as the estimation technique, the authors find that nonlinear relationship between poverty and carbon dioxide emissions worsen poverty and environmental degradation. However, strong institutional quality strengthens environmental quality and leads to reduction in poverty. Furthermore, Khan [35] explores the relationship between poverty and environment nexus in Pakistan. The author finds that the popular belief that poverty worsens environmental degradation cannot be supported by empirical evidence. Rather, the findings show that environmental degradation hurts the poor more.

Besides, Gohou and Soumare [23] examine the direct relationship between foreign direct investment and welfare (poverty reduction) in 52 African countries from 1990 to 2007. Outcomes of the study show positive and significant relationship between foreign direct investment and poverty reduction. Furthermore, the authors conclude that the effect of foreign direct investment on poverty reduction is more felt among poorer countries than wealthier countries. Still in light of direct relationship between foreign direct investment and poverty, Muhammad et al. [45] found that foreign direct investment contributes significantly to poverty reduction in Pakistan using ARDL bound testing approach between the period 1985-2016. Similarly, Tsaurai [66] investigate the complementarity between foreign direct investment and natural resources in reducing poverty in southern and western African countries from 2002 to 2012. Using different of methodologies and different proxies for poverty, finding from the study shows that interaction between foreign direct investment and natural resources reduces poverty level in African countries.

Contrary to the position in the theoretical literature of positive effect of foreign direct investment in reducing poverty, Huang et al. [28], Ali et al. [2], Tsai and Huang [65] and Akinmulegun [1] among others conclude is there studies that foreign direct investment worsening poverty position of a country.

This study therefore deviates from extant studies that have examined the relationship among foreign direct investment, environmental degradation and poverty by determining the optimum level of environmental degradation beyond which foreign direct investment will translate to poverty reduction in African countries.

\section{Methods}

\section{Model specification}

To investigate whether the effect of foreign direct investment on poverty reduction will be affected by the environmental degradation in sub-Saharan Africa, we adopt a panel threshold estimator. Hansen [26] developed a panel threshold estimator, but this threshold estimator is appropriate for static and balanced panels only. Due to persistence which is usually common to some macroeconomic variables, we discovered that a dynamic panel framework is more suitable. To examine nonlinearity in dynamic panel data, Bick [6] and Kremer et al. [38] proposed a dynamic panel threshold estimator which is an extension of the threshold models by Hansen [26, 27], and Caner and Hansen [11]. We, therefore, follow this methodology proposed by Kremer et al. [38] to investigate the threshold effect of environmental degradation on foreign direct investment-poverty reduction nexus. The model is specified as,

$$
\begin{aligned}
\operatorname{Pov}_{i t}= & \mu_{i}+\delta_{1} l\left(\mathrm{env}_{i t} \leq \gamma_{i t}\right)+\beta_{1}\left(\mathrm{fdi}_{i t}\right) l\left(\mathrm{env}_{i t} \leq \gamma_{i t}\right) \\
& +\beta_{2}\left(\mathrm{fdi}_{i t}\right) l\left(\mathrm{env}_{i t}>\gamma_{i t}\right)+\sigma_{1} \operatorname{pov}_{i t-1}+\sigma_{2} X_{i t}+\varepsilon_{i t}
\end{aligned}
$$

where, $\operatorname{pov}_{i, t}$ stand for poverty for country $i$ at the period $t$. fdi represents a foreign direct investment, env stands for environmental quality, $\operatorname{pov}_{i t-1}$ is the lagged poverty which is also the right-hand side endogenous variable. $X_{i t}$ represents the control variables. $\mu_{i}$ indicates country-specific fixed effects. $I($.$) is an indicator function and$ depending on whether the threshold variable is larger or smaller than $\gamma$, it divides the observations into two regimes distinguished by differing regression slopes [16], $\beta_{1}$ and $\beta_{2} . \delta_{1}$ is the regime intercept which is the same for all individuals.

\section{Data and measurement of variables}

Poverty reduction is the dependent variable and is measured by three indicators. The first measure is household final consumption expenditure per capita (HCE) while life expectancy (LEX) and human development index (HDI) $[15,18,23,42,69]$ are the second and third measures. The human development index (HDI) is instituted by UNDP to indicate a deeper and sustainable poverty reduction perspective that takes life expectancy, education, and standard of living into consideration. Data on household final consumption as well as that of life expectancy are obtained from the World Bank Development Indicator [64]. We source data on the Human Development Index from Africa Development Indicator (2019).

Likewise, we measure environmental degradation through three indicators. Carbon dioxide $\left(\mathrm{CO}_{2}\right)$ emission per capita is our first measure of environmental degradation which happens to be the most common proxy for environmental degradation in the literature. For instance, several studies such as Kivyiro and Arminen [39], Ren et al. [52] and recent studies like Sarkodie and Strezov [57] and Dhrifi et al. [18] proxied environmental degradation by carbon dioxide $\left(\mathrm{CO}_{2}\right)$. However, for this study to provide a clear understanding of the diverse dynamics 
of environmental degradation we use methane emissions ( $\mathrm{kt}$ of $\mathrm{CO}_{2}$ equivalent) and nitrous oxide emissions (thousand metric tons of $\mathrm{CO}_{2}$ equivalent) as other measures of environmental degradation. We use nitrous oxide emissions and methane emissions as alternative measures of environmental degradation because GISS Surface Temperature Analysis [22] and Intergovernmental Panel on Climate Change [30] classified them as one of the sources of global warming. Kubicova [40] and Opoku and Boachie [48] also used nitrous oxide emission and methane emission to measure environmental degradation. The three proxies of environmental degradation are obtained from the World Bank Development Indicator [64].

Foreign Direct Investment (FDI) is obtained from the World Bank Development Indicator [64] and is the average of FDI net inflows to GDP. We include some control variables which include; trade openness, inflation, financial development and corruption. The choice of the control variables included is based on their relevance and roles in FDI and poverty nexus. Also, these control variables are considered in the literature as important variables in explaining the poverty reduction. Trade openness is the sum of export and import (as \% of GDP). Inflation is measured as the annual percentage of the consumer price index. Financial development is measured by domestic credit to private sector. Corruption is the evaluation of corruption within the political system. It concerns with the possible corruption in the form of extreme sponsorship, favouritism, job reservations, 'favour-for-favours', secret party funding, and questionably link between politics and business. Corruption control is rated between 0 and 6 . A score of 6 points suggests a low level of corruption, while 0 point indicates a high level of corruption. Data on corruption are obtained from the International Country Risk Guide [31] while data on trade openness, financial development and inflation are obtained from the World Development Indicator [64]. This study included 39 sub-Saharan African countries and spans from 1986 to 2018. We present the list of the countries included in the study in the "Appendix". The choice of the sample size and time frame of this study is dictated by data availability. The descriptive statistics of the variables are presented in Table 1.

\section{Results}

We present the results of Eq. 1 in Tables 2, 3, and 4. In Table 2, we use household final consumption expenditure as the proxy for poverty reduction. We use life expectancy and human development index to proxy poverty reduction in Tables 3 and 4, respectively. In each of the Tables, we use carbon dioxide emission as the measure for environmental degradation in the first column. In the second column, we use methane emissions as the
Table 1 Descriptive statistics

\begin{tabular}{lrrll}
\hline Variables & Mean & SD & Min & Max \\
\hline $\begin{array}{l}\text { Human consumption } \\
\quad \text { expenditure }\end{array}$ & 1123.26 & 1205.089 & 116.461 & 7252.202 \\
Life expectancy & 72.539 & 31.884 & 11.8 & 168.7 \\
$\begin{array}{l}\text { Human development } \\
\quad \text { index }\end{array}$ & 0.441 & 0.123 & 0.198 & 0.804 \\
Foreign direct investment & 3.008 & 5.372 & -28.624 & 57.838 \\
Carbon dioxide emission & 0.855 & 1.722 & 0.011 & 9.979 \\
Methane emissions & $15,297.64$ & $22,191.88$ & 15.213 & 189,678 \\
Nitrous oxide emissions & 9939.049 & $17,498.76$ & 12.64 & $172,723.3$ \\
Inflation & 42.134 & 737.646 & -60.496 & $23,773.13$ \\
Financial development & 19.095 & 22.408 & 0.403 & 160.125 \\
Trade openness & 65.026 & 35.947 & 9.139 & 225.023 \\
Corruption & 2.356 & 1.025 & 0 & 6 \\
\hline
\end{tabular}

measure of environmental degradation while in the third column, we use nitrous oxide emissions to measure environmental degradation.

Starting with Table 2, we estimate threshold values of 1.105, for carbon dioxide emission, 3.720 and 3.197 for methane emission and nitrous emission, respectively. Below the threshold level in the first column, we found that the coefficient of foreign direct investment is negative but insignificant. However, above the threshold level, the coefficient of foreign direct investment is positive and significant. This is an indication that above the threshold level, FDI enhances poverty reduction. This is contrary to what is obtained in the second column where methane emission is used as a threshold variable. Below the threshold level, foreign direct investment significantly enhances poverty reduction while above the threshold level, foreign direct investment produces no effect on poverty. In the third column, where nitrous oxide emission is used to proxy environmental degradation, foreign direct investment failed to significantly impact poverty below and above the estimated threshold value. Regarding the regime intercept $\delta_{1}$, Bick [6] stated that it signifies that the difference in the regime intercepts is not individual-specific, but the same for all cross-sections. This indicates that the growth rate of poverty reduction in the same regime is identical, but not different across countries within the regime. The inclusion of regime intercept $\delta_{1}$ in the model reduces the biases of omitting variables based on a statistic perspective. The coefficients of regime intercept $\delta_{1}$ are positive and significant in all the models.

On the control variables, the coefficient of inflation is positive but insignificant in all the models. This indicates that inflation has no effect on poverty during the study period. Financial development significantly contributed to poverty reduction as its coefficient is significant at 
Table 2 Results of the dynamic threshold effect of the environmental degradation on foreign direct investment and poverty reduction (dependent variable: household final consumption expenditure)

\begin{tabular}{llll}
\hline & Carbon dioxide emission $\left(\mathrm{CO}_{2}\right)$ & Methane emission & $\begin{array}{c}\text { Nitrous oxide } \\
\text { emission }\end{array}$ \\
\hline $\begin{array}{l}\text { Threshold estimates } \\
\hat{\gamma}\end{array}$ & 1.105 & 3.720 & 3.197 \\
Foreign direct investment & & & $13.530(0.160)$ \\
$\hat{\beta}_{1}$ & $-3.145(0.196)$ & $9.832^{* *}(0.038)$ & $0.363(0.900)$ \\
$\hat{\beta}_{2}$ & $36.745^{* * *}(0.000)$ & $-2.126(0.498)$ & $0.881^{* * *}(0.000)$ \\
Control variables & & $0.877^{* * *}(0.000)$ & $0.002(0.811)$ \\
L. Household final consumption expenditure & $0.874^{*}(0.072)$ & $0.002(0.829)$ & $3.922^{* * *}(0.000)$ \\
Inflation & $0.002(0.859)$ & $3.965^{* * *}(0.000)$ & $1.912^{* * *}(0.000)$ \\
Financial development & $3.351^{* * *}(0.000)$ & $1.869^{* * *}(0.000)$ & $11.553(0.316)$ \\
Trade openness & $1.602^{* * *}(0000)$ & $11.360(0.322)$ & $91.353^{* *}(0.015)$ \\
Corruption & $15.356(0.145)$ & $83.380^{* *}(0.027)$ & 451 \\
$\hat{\delta}_{1}$ & $61.745^{*}(0.072)$ & 39 & 39 \\
No. of observation & 503 & & 451 \\
No. of countries & 39 & & 39 \\
\hline
\end{tabular}

$* * *$, ** * Implies significance at $1 \%, 5 \%$ and $10 \%$, respectively

The probability values are in parentheses

Table 3 Results of the dynamic threshold effect of the environmental degradation on foreign direct investment and poverty reduction (dependent variable: life expectancy)

\begin{tabular}{llll}
\hline & Carbon dioxide emission $\left(\mathrm{CO}_{2}\right)$ & Methane emissions & $\begin{array}{l}\text { Nitrous oxide } \\
\text { emissions }\end{array}$ \\
\hline $\begin{array}{l}\text { Threshold estimates } \\
\hat{\gamma}\end{array}$ & 0.125 & 4.278 & 3.807 \\
$\begin{array}{l}\text { Foreign direct investment } \\
\hat{\beta}_{1}\end{array}$ & $0.100^{* * *}(0.001)$ & $0.046^{* *}(0.025)$ & $0.039^{*}(0.061)$ \\
$\hat{\beta}_{2}$ & $0.039^{* *}(0.026)$ & $0.130^{* * *}(0.001)$ & $0.123^{* * *}(0.000)$ \\
Control variables & & & $0.882^{* * *}(0.000)$ \\
L. Life expectancy & $0.906^{* * *}(0.000)$ & $-0.0002(0.821)$ & $-0.0001(0.827)$ \\
Inflation & $-0.0002(0.748)$ & $0.006^{*}(0.072)$ & $0.006^{*}(0.056)$ \\
Financial development & $0.006^{* *}(0.031)$ & $0.012^{* * *}(0.000)$ & $0.012^{* * *}(0.000)$ \\
Trade openness & $0.010^{* * *}(0.000)$ & $-0.066(0.351)$ & $-0.081(0.253)$ \\
Corruption & $-0.106(0.115)$ & $5.647^{* * *}(0.000)$ & $5.539^{* * *}(0.000)$ \\
$\hat{\delta}_{1}$ & $4.605^{* * *}(0.000)$ & 617 & 617 \\
No. of observation & 673 & 39 & 39 \\
No. of countries & 39 & &
\end{tabular}

***, *****mplies significance at $1 \%, 5 \%$ and $10 \%$, respectively

The probability values are in parentheses

$1 \%$ in all the models. This is in line with Sehrawat and Giri [58], Boukhatem [8] and Rewilak [54], Keho [36] who found that financial development enhances poverty reduction. Trade openness produces a positive effect on poverty which means that trade openness contributed to poverty reduction. This is consistent with Onakoya et al. [47] who found that trade openness reduces poverty levels in sub-Saharan Africa. Corruption has no effect on poverty as its coefficient is not significant in all the models. The lagged household final consumption expenditure contributes to the current final consumption expenditure. 
Table 4 Results of the dynamic threshold effect of the environmental degradation on foreign direct investment and poverty reduction (dependent variable: human development index)

\begin{tabular}{llll}
\hline & Carbon dioxide emission $\left(\mathrm{CO}_{2}\right)$ & Methane emission & $\begin{array}{c}\text { Nitrous oxide } \\
\text { emission }\end{array}$ \\
\hline $\begin{array}{l}\text { Threshold estimates } \\
\hat{\gamma}\end{array}$ & 1.819 & 4.299 & 3.849 \\
Foreign direct investment & $0.0001(0.737)$ & $0.0001(0.838)$ & $-0.0005(0.867)$ \\
$\hat{\beta}_{1}$ & $0.001^{* *}(0.044)$ & $0.001^{* *}(0.044)$ & $0.001^{* *}(0.032)$ \\
$\hat{\beta}_{2}$ & & $0.936^{* * *}(0.000)$ & $0.934^{* * *}(0.000)$ \\
Control variables & $0.937^{* * *}(0.000)$ & $-3.611(0.720)$ & $-3.811(0.705)$ \\
L. Human development index & $-3.610(0.720)$ & $0.001^{* *}(0.013)$ & $0.001^{* * *}(0.007)$ \\
Inflation & $0.001^{* *}(0.013)$ & $0.0002^{* * *}(0.000)$ & $0.0002^{* * *}(0.000)$ \\
Financial development & $0.0002^{* * *}(0.000)$ & $0.002(0.133)$ & $0.001(0.237)$ \\
Trade openness & $0.002(0.133)$ & $0.012^{* * *}(0.005)$ & $0.013^{* * *}(0.004)$ \\
Corruption & $0.012^{* * *}(0.005)$ & 617 & 617 \\
$\hat{\delta}_{1}$ & 617 & 39 & 39 \\
No. of observation & 39 & & \\
No. of countries & & & \\
\hline
\end{tabular}

***, ${ }^{* *},{ }^{*}$ Implies significance at $1 \%, 5 \%$ and $10 \%$, respectively

The probability values are in parentheses

In Table 3, where we use life expectancy to proxy poverty reduction, in the first column we estimate a threshold value of 0.125 for carbon dioxide emission. In the second column, a threshold value of 3.278 is obtained for methane emission, while we obtained a threshold value of 3.807 for nitrous oxide emission in the third column. We found that at the lower and higher level of carbon dioxide emission, FDI has a positive and significant effect on poverty reduction. However, the coefficient of FDI is bigger at the lower level of carbon dioxide emission which indicates that FDI contributes more to poverty reduction when carbon dioxide emission is lower. Likewise, in the second column, FDI contributes to poverty reduction below and above the threshold level. However, based on the coefficient value, FDI contributes more to poverty reduction above the threshold level. In the third column, the coefficients of FDI are positive and significant in the two regimes. However, by comparing the coefficients of FDI in the two regimes, the coefficient of FDI is bigger above the threshold level. This implies that a higher level of nitrous oxide emissions is not detrimental to poverty reduction effect of FDI. The regime intercept is positive and significant in all the models. Regarding the control variables, like in Table 2 , inflation produces no effect on poverty. Financial development reduces the level of poverty in all models. Trade openness proves to be a major determinant of poverty reduction as it produces a positive and significant effect on poverty. Corruption failed to significantly impact poverty reduction. Lagged life expectancy contributes positively to current life expectancy.
As we indicated earlier, the human development index is used as the measure for poverty reduction in Table 4 . From the results, a threshold value of 1.819 is estimated for carbon dioxide emission in the first column. For methane emission in the second column, the estimated threshold value is 4.299 while a threshold value of 3.849 is estimated for nitrous oxide emission in the third column. For the first column, where environmental degradation is measured by carbon dioxide emission, FDI produces a positive but insignificant effect on poverty reduction below the threshold level. But the coefficient of FDI becomes significant above the threshold value. This means that FDI enhances poverty reduction above the threshold value. The same result is obtained in the second column where we measured environmental degradation by methane emission. Below the threshold level, the impact of FDI on poverty reduction is insignificant positive. Above the threshold level, the coefficient of FDI is positive and significant. This is indicating that FDI significantly contributed to poverty reduction above the threshold level. A slightly different result is obtained in the third column where environmental degradation is proxied by nitrous oxide emission. Below the threshold value, the coefficient of FDI is insignificant negative. However, above the threshold level, FDI significantly contributed to poverty reduction. These findings show that environmental degradation is not harmful to the poverty reduction effect of FDI.

Like in earlier Tables, inflation and corruption produce an insignificant effect on poverty. However, financial development is beneficial to poverty reduction. 
The coefficient of trade openness remains positive and significant like in other Tables. The coefficient of the lagged human development index is positive and significant. This suggests that the lagged human development index enhances the current human development index.

\section{Discussion}

We found that the higher level of carbon dioxide emission enhances the poverty reduction effect of FDI. This implies that carbon dioxide emission is not eroding the benefit of FDI in reducing poverty. Evidence from our findings shows that the influence of methane emission on the FDI-poverty nexus is sensitive to the poverty measures used. For instance, when household final consumption expenditure is used to measure poverty, FDI promotes poverty reduction when methane emission is below the threshold. But when life expectancy is used as a proxy for poverty, FDI contributes more to poverty reduction when methane emission is above the threshold value. Contrary to when household final consumption is used to proxy poverty, above the threshold level of methane emission, FDI contributes to poverty reduction when the human development index is used to proxy poverty. This is an indication that while lower methane emission is good for poverty reduction effect of FDI when household final consumption is used as proxied for poverty, higher methane emission is, however, good for poverty reduction effect of FDI when poverty is proxied by life expectancy and human development index. Likewise, the role of nitrous oxide emission in FDI-poverty depends on the proxy of poverty used. When household consumption expenditure is used as a proxy, FDI produces no effect on poverty contrary to other measures of environmental degradation. However, with life expectancy and human development index as proxies for poverty, we found that FDI reduces the rate of poverty when nitrous oxide emission is above the threshold. Generally, we found overwhelming evidence that environmental degradation is not harmful to the poverty reduction effect of FDI. This suggests that the inflow of FDI might not contribute to environmental degradation as much as it is generally believed. This might be a surprise; however, Jugurnath and Emrith [34] found that the increase in the inflow of FDI does not significantly contribute to an increase in the levels of $\mathrm{CO}_{2}$ emissions in SIDS countries. It has also been argued that FDI is less pollutant than domestic producers as FDI uses new technologies that are cleaner than domestic producers; therefore, the inflow of FDI will significantly improve the environmental quality. Likewise, Wilhelms [72] and Pigato [49] stated that the attraction of FDI and as well maximizing its benefits and minimizing its risk by developing countries is depending on the effectiveness of their policy and institutions which suggest that environmental degradation might not be a major issue if appropriate policies are adopted.

The study found that financial development enhances poverty reduction. According to Keho [36], financial development can directly reduce poverty by easing transactions and enable the poor to have access to financial services that boost their income. McKinnon [44] stated that even the poor might not have access to credit facilities of the financial institutions but financial institutions still make transaction services and saving opportunities available which enhances the income of the poor and hence poverty. Shahbaz [59] and Inoue and Hamori [32] claimed that the access of the poor to credit and financial services reinforce their productive assets through the use of productivity-enhancing technologies or investing in education and health, which in turn increases their income and thus lowers the rate of poverty. Aside from the direct effect of financial development on poverty reduction, De Gregorio [17] stated that financial development can also indirectly reduce poverty rates by stimulating economic growth.

The effect of inflation on poverty is insignificant in all the estimations. However, evidence from the literature shows that there are mixed results on the impact of inflation on poverty. Some studies (e.g., $[9,12,13,50$, 51]) established a positive correlation between inflation and poverty, while some other studies produce otherwise results (e.g., $[7,14,56]$.

Trade openness contributed significantly to poverty reduction in this study. Le Goff and Singh [41] found that trade openness reduces poverty in sub-Saharan Africa countries that have deep financial sectors and strong institutional quality. Trade openness can reduce poverty by increasing economic activities, ideas and innovations for the poor. Theoretically, it has been argued that trade openness can change relative factor prices in favor of the more abundant factor and if labor surplus is the cause of the low level of income and increase in poverty, then expansion of trade openness will stimulate an increase in labor prices and hence reduces poverty. Though the relationship between trade openness and poverty is not without controversy in the literature as there is no consensus on the relationship. For instance, Beck et al. [5] and Kpodar and Singh [37] find no effect of trade openness on poverty, while Guillaumont-Jeanneney and Kpodar [24] found that trade openness reduces the income of the poor and Singh and Huang [61] found that trade openness increases the poverty rate.

There is no significant relationship between poverty and corruption in this study. However, corruption 
is seen as an obstacle to poverty reduction as it leads to the diversion of scarce resources, preventing the poor from having access to basic social amenities and resources which can enhance their livelihoods. Gupta et al. [25] stated that corruption promotes income inequality and poverty by slowing down economic growth.

\section{Conclusion}

This study investigates the threshold effect of environmental degradation in the relationship between FDI and poverty in sub-Saharan Africa over the period 19862018. To provide valid and robust results, we employed $\mathrm{CO}_{2}$, methane emission and nitrous oxide emission as proxies for environmental degradation. In the same way, household final consumption expenditure, life expectancy and human development index are used to measure poverty. The study employed dynamic panel threshold regression proposed by Kremer et al. [38].

The empirical results from the threshold regression showed that environmental degradation is not detrimental to the poverty reduction effect of FDI during the study period. Two implications can be drawn from this finding. First, any policy employed to reduce the level of $\mathrm{CO}_{2}$, methane emission and nitrous oxide by preventing the inflow of FDI into the region will be detrimental to the poverty reduction effect of FDI in the region. Therefore, policies that target a cleaner environment without reducing the inflow FDI is necessary as it will also boost the poverty reduction impact of FDI. The introduction of energy-efficient technologies will also help to reduce the level of environmental degradation without limiting the inflow of FDI in the region. Second, more inflow of FDI is still necessary in the region in solving the problem of poverty as the region is regarded as the poorest region in the world. This is very germane as the region lacks sufficient capital required for development and hence poverty. More inflow of FDI will supplement the available domestic capital to transform the economies in the region by increasing employment, production, exports and per capita income.

The study also found that financial development contributes to poverty reduction in the region. This finding implies that more effort is required from the policymakers to increase the level of financial deepening for more impact of financial development on poverty reduction in the region. Evidence from past studies indicates that the financial sector in sub-Saharan Africa is among the least developed across the world. Likewise, policies that will increase access of poor people to credit facilities and other financial services will significantly reduce the level of poverty.

It is important to give a hint that this study has contributed to the literature by examining the threshold effect of environmental degradation in foreign direct investmentled poverty reduction in sub-Saharan African countries.
Table 5 List of countries

\begin{tabular}{llll}
\hline Angola & Congo Republic & Madagascar & Seychelles \\
Benin & Cote d'Ivoire & Malawi & Sierra Leone \\
Botswana & Eswatini & Mali, & South Africa \\
Burkina Faso & Equatorial Guinea & Mauritania & Sudan \\
Burundi, & Gabon & Mozambique & Tanzania \\
Cape Verde & The Gambia & Namibia & Togo \\
Cameroon & Ghana & Niger & Uganda \\
Central African Rep & Guinea Bissau & Nigeria & Zambia \\
Chad & Kenya, & Rwanda & Zimbabwe \\
Congo democratic & Lesotho & Senegal & \\
\hline
\end{tabular}

Further, no known study from sub-Saharan Africa has examined this relationship, thereby making the study different. However, this study is limited based on the availability of data on other proxies of poverty such as poverty headcount ratio and poverty gap. Further, this study can be extended to other developing countries especially countries in Latin America and Asian continents.

\section{Appendix}

See Table 5.

\section{Abbreviations}

FDI: Foreign direct investment; $\mathrm{CO}_{2}$ : Carbon dioxide emissions; HDI: Human development index; LEX: Life expectancy.

\section{Acknowledgements \\ Not applicable.}

\section{Authors' contributions}

JTD writes the introduction and proofreading the study on Foreign Direct Investment and Poverty Reduction in Sub-Saharan Africa: Does Environmental Degradation Matter? TA analyzed and interpreted the results for the study. Both authors read and approved the final manuscript.

\section{Funding}

This work does not receive any funding.

\section{Availability of data and materials}

The datasets used during the current study are available from the corresponding author on reasonable request.

\section{Declarations}

Competing interests

The authors declare that they have no competing interests.

\section{Author details}

${ }^{1}$ Department of Economics, Obafemi Awolowo University, Ile-Ife, Nigeria.

${ }^{2}$ Department of Economics, Adeyemi College of Education, Ondo, Nigeria.

Received: 15 December 2020 Accepted: 13 April 2021

Published: 14 June 2021 


\section{References}

1. Akinmulegun SO (2012) Foreign direct investment and standard of living in Nigeria. J Appl Finance Bank 2(3):295-309

2. Ali M, Nishat M, Anwar T (2010) Do foreign inflows benefit Pakistan poor? Pak Dev Rev 48(4):715-738. https://doi.org/10.30541/v48i4llpp.715-738

3. Agarwal M, Atri P, Kundu S (2017) Foreign direct investment and poverty reduction: India in regional context. South Asia Econ J 18(2):135-157

4. Anetor FO, Esho E, Verhoef G, Christian N (2020) The impact of foreign direct investment, foreign aid and trade on poverty reduction: evidence from Sub-Saharan African countries. Cogent Econ Finance. https://doi. org/10.1080/23322039.2020.1737347

5. BeckT, Demirguc-Kunt A, Levine R (2007) Finance, inequality and the poor. J Econ Growth 12:27-49

6. Bick A (2010) Threshold effects of inflation on economic growth in developing countries. Econ Lett 108(2):126-129

7. Blank RM, Blinder AS (1985) Macroeconomics, income distribution, and poverty. NBER working paper no.1567, Cambridge, MA

8. Boukhatem J (2015) Assessing the direct effect of financial development on poverty reduction in a panel of low-and middle-income countries. Res Int Bus Finance 37:214-230. https://doi.org/10.1016/j.ribaf.2015.11.008

9. Braumann B (2004) High inflation and real wages. IMF staff papers, vol 51, no 1. Palgrave Macmillan, pp 1-6

10. Calvo CC, Hernandez MA (2006) Foreign direct investment and poverty in Latin America. Leverhulme Centre for Research on Globalization and Economic Policy, University of Nottingham

11. Caner M, Hansen BE (2004) Instrumental variable estimation of a threshold model. Econom Theor 20(5):813-843

12. Cardoso E (1992) Inflation and Poverty. NBER working paper. no. 4006 Cambridge, MA

13. Chauhary TT, Chaudhary AA (2008) The effects of rising food and fuel costs on poverty in Pakistan. The Lahore Journal of Economics, Special Edition (September), Lahore, Pakistan, pp 117-138

14. Cutler DM, Katz LF (1991) Macroeconomic performance and the disadvantaged. Brook Pap Econ Act 22(2):1-74

15. Dada JT, Fanowopo O (2020) Economic growth and poverty reduction: the role of institutions. Ilorin J Econ Policy 7(1):1-15

16. Dada JT, Abanikanda EO (2019) How important is oil revenue in Nigerian growth process? Evidence from a threshold regression. Int J Sustain Econ 11(4):364-377. https://doi.org/10.1504/IJSE.2019.10025140d

17. De Gregorio J (1996) Borrowing constraints, human capital accumulation and growth. J Monet Econ 37:49-71

18. Dhrifi A, Jaziri R, Alnahdi S (2019) Does foreign direct investment and environmental degradation matter for poverty? Evidence from developing countries. Struct Change Econ Dyn. https://doi.org/10.1016/j.strueco. 2019.09.008

19. Fauzel S, Seetanah B, Sannassee RV (2015) Foreign direct investment and welfare nexus in sub Saharan Africa. J Dev Areas 49(4):271-283

20. Fowowe B, Shuaibu MI (2014) Is foreign direct investment good for the poor? New evidence from African countries. Eco Change Restruct 47:321-339

21. Ganić M (2019) Does foreign direct investment (FDI) contribute to poverty reduction? Empirical evidence from Central European and Western Balkan countries. Sci Ann Econ Bus 66(1):15-27

22. GISS Surface Temperature Analysis (2019) GISTEM version is v3. https:// data.giss.nasa.gov/gistemp

23. Gohou G, Soumare I (2012) Does foreign direct investment reduce poverty in Africa and are there regional differences? World Dev 40:75-95. https://doi.org/10.1016/j.worlddev.2011.05.014

24. Guillaumont-Jeanneney S, Kpodar K (2011) Financial development and poverty reduction: can there be a benefit without a cost? J Dev Stud 47(1):143-163

25. Gupta S, Davoodi H, Alonso-Terme R (1998) Does corruption affect income inequality and poverty? IMF working paper no. 98/76, Available at SSRN: https://ssrn.com/abstract $=882360$

26. Hansen BE (1999) Threshold effects in non-dynamic panels: estimation, testing, and inference. J Econom 93(2):345-368

27. Hansen BE (2000) Sample splitting and threshold estimation. Econometrica 68(3):575-603

28. Huang C, Teng K, Tsai P (2010) Inward and outward foreign direct investment and poverty reduction: East Asia versus Latin America. Rev World Econ 146(4):763-779
29. Hung TT (1999) Impact of foreign direct investment on poverty reduction in Vietnam. ID Program, GRIPS

30. Intergovernmental Panel on Climate Change (2014) Summary for policymakers. In: Climate Change 2014: mitigation of climate change. Contribution of working group III to the fifth assessment report of the intergovernmental panel on climate change. Cambridge University Press, UK and New York, NY, USA

31. International Country Risk Guide (ICRG) Researchers (2019) International country risk guide (ICRG) Researchers Dataset. Harvard Dataverse, V8. https://doi.org/10.7910/DVN/4YHTPU

32. Inoue T, Hamori S (2012) How has financial deepening affected poverty reduction in India? Empirical analysis using state-level panel data. Appl Financial Econ 22(5):395-408

33. Jemiluyi OO, Dada JT (2018) Market size and foreign direct investment in Sub-Saharan Africa: the role of education. Jurnal Perspektif Pembiayaan dan Pembangunan Daerah (J Perspect Financing Reg Dev) 6(1):21-30. https://doi.org/10.22437/ppd.v6i1.5140

34. Jugurnath B, Emrith $A$ (2018) Impact of foreign direct investment on environment degradation: evidence from SIDS countries. J Dev Areas $52(2): 13-26$

35. Khan H (2008) Poverty, environment and economic growth: exploring the links among three complex issues with specific focus on the Pakistan's case. Environ Dev Sustain 10:913-929. https://doi.org/10.1007/ s10668-007-9092-5

36. Keho Y (2017) Financial development and poverty reduction: evidence from selected African countries. Int J Financial Res 8:90-98

37. Kpodar K, Singh R (2011) Does financial structure matter for poverty? Evidence from developing countries. World Bank policy research working paper, WPS5915

38. Kremer S, Bick A, Nautz D (2013) Inflation and growth: new evidence from a dynamic panel threshold analysis. Empir Econ 44(2):861-878

39. Kivyiro P, Arminen H (2014) Carbon dioxide emissions, energy consumption, economic growth, and foreign direct investment: causality analysis for Sub-Saharan Africa. Energy 74(C):595-606

40. Kubicova J (2014) Testing greenhouse gasses in Slovakia for environmental Kuznets curve and pollution haven hypothesis. J Int Stud 7(2):161-177

41. Le Goff M, Singh RJ (2014) Does trade reduce poverty? A view from Africa. J. Afr Trade 1(1):5-14. https://doi.org/10.1016/j.joat.2014.06.001

42. Magombeyi MT, Odhiambo NM (2017) Causal relationship between FDI and poverty reduction in South Africa. Cogent Econ Finance 5:1357901. https://doi.org/10.1080/23322039.2017.1357901

43. Meyer KE, Sinani E (2009) When and where does foreign direct investment generate positive spillover? A meta-analysis. J Int 40:1075-1094

44. McKinnon RI (1973) Money and capital in economic development. Brooking Institution, Washington

45. Muhammad BK, Xie H, Hummera S (2019) Direct impact of inflow of foreign direct investment on poverty reduction in Pakistan: a bonds testing approach. Econ Res Ekon Istraž 32:3647-3666. https://doi.org/10.1080/ $1331677 \times .2019 .1670088$

46. Ogunniyi MB, Igberi CO (2014) The impact of foreign direct investment on poverty reduction in Nigeria. J Econ Sustain Dev 5(14):73-89

47. Onakoya A, Johnson B, Ogundajo G (2019) Poverty and trade liberalization: empirical evidence from 21 African countries. Econ Res Ekon Istraž 32(1):635-656. https://doi.org/10.1080/1331677X.2018.1561320

48. Opoku EEO, Boachie MK (2020) The environmental impact of industrialization and foreign direct investment. Energy Policy 137:111178

49. Pigato MA (2001) The foreign direct investment environment in Africa. World Bank Africa region working paper series no. 15

50. Powers ET (1995) Inflation, unemployment, and poverty revisited. Fed Reserve Bank Clevel Econ Rev 31(3):2-13

51. Ravallion M (1998) Reform, food prices and poverty in India. Econ Polit Wkl 33(1/2):29-36

52. Ren S, Yuan B, Ma X, Chen X (2014) International trade, FDI (foreign direct investment) and embodied $\mathrm{CO}_{2}$ emissions: a case study of Chinas industrial sectors. China Econ Rev 28:123-134

53. Reiter SL, Steensma HK (2010) Human development and foreign direct investment in developing countries: the influence of foreign direct investment policy and corruption. World Dev 38:1678-1691

54. Rewilak J (2017) The role of financial development in poverty reduction. Rev Dev Finance 7(2017):169-176 
55. Rizk R, Slimane MB (2018) Modelling the relationship between poverty, environment, and institutions: a panel data study. Environ Sci Pollut Res 25(3):31459-31473

56. Romer CD, Romer DH (1999) Monetary policy and the well-being of the poor. Econ Rev 84(Q1):21-49

57. Sarkodie SA, Strezov V (2019) Effect of foreign direct investments, economic development and energy consumption on greenhouse gas emissions in developing countries. Sci Total Environ 646:862-871

58. Sehrawat M, Giri AK (2016) Financial development, poverty and ruralurban income inequality: evidence from South Asian countries. Qual Quant Int J Methodol 50(2):577-590

59. Shahbaz M (2009) Financial performance and earnings of poor people: a case study of Pakistan. J Yasar Univ 4:2557-2572

60. Shahbaz M, Nasreen S, Abbas F, Anis O (2015) Does foreign direct investment impede environmental quality in high-, middle-, and low-income countries? Energy Econ 51:275-287

61. Singh R, Huang Y (2011) Financial deepening, property rights, and poverty: evidence from sub-Saharan Africa. IMF working paper, WP/11/196. International Monetary Fund, Washington

62. Soumare I (2015) Does Foreign Direct Investment Improve Welfare in North Africa? Africa Development Bank

63. Sumner A (2005) Is foreign direct investment good for the poor? A review and stock take. Dev Pract 15:269-285

64. The World Bank (2019) World development indicators. The World Bank, Washington, DC

65. Tsai P, Huang C (2007) Openness, growth and poverty: the case of Taiwan. World Dev 35:1858-1871. https://doi.org/10.1016/j.worlddev.2006.11.013

66. Tsaurai K (2018) Investigating the impact of foreign direct investment on poverty reduction efforts in Africa. Rev Galega Econ 27(2):139-154
67. Ucal MS (2014) Panel data analysis of foreign direct investment and poverty from the perspective of developing countries. Soc Behav Sci 109:1101-1105

68. United Nation Conference on Trade and Development (UNCTAD) (2019) World investment report 2019

69. Uttama NP (2015) Foreign direct investment and the poverty reduction nexus in Southeast Asia. Economic studies in inequality, social exclusion, and well-being. In: Heshmati A, Maasoumi E, Wan G (eds) Poverty reduction policies and practices in developing Asia, 127th ed, pp 281-298

70. Wang $H$, Huifang $L$ (2019) Foreign direct investment, environmental regulation, and environmental pollution: an empirical study based on threshold effects for different Chinese regions. Environ Sci Pollut Res 26:5394-5409. https://doi.org/10.1007/s11356-018-3969-8

71. Wang H, Liu H (2019) Foreign direct investment, environmental regulation, and environmental pollution: An empirical study based on threshold effects for different Chinese regions. Environ Sci Pollut Res 26(6):5394-5409

72. Wilhelms SKS (1998) Foreign direct investment and its determinants in emerging economies. African economic policy paper discussion paper number 9, USAID

73. World Data Lab's Poverty Clock (2018) www.worlddata.io/portfolio/worldpoverty-clock

74. Zhang YJ (2011) The impact of financial development on carbon emissions: an empirical analysis in China. Energy Policy 39:2197-2203

\section{Publisher's Note}

Springer Nature remains neutral with regard to jurisdictional claims in published maps and institutional affiliations.

\section{Submit your manuscript to a SpringerOpen ${ }^{\circ}$ journal and benefit from:}

- Convenient online submission

- Rigorous peer review

- Open access: articles freely available online

- High visibility within the field

- Retaining the copyright to your article

Submit your next manuscript at springeropen.com 